\title{
Protoplast isolation from Dictyopteris pacifica and Scytosiphon lomentaria, using a simple commercial enzyme preparation
}

\author{
Jose Avila-Peltroche ${ }^{1,2}$ (D), Boo Yeon Won ${ }^{1}$ (D) and Tae Oh Cho ${ }^{1,2^{*}}$ (D)
}

\begin{abstract}
Background: Protoplasts (i.e., naked plant cells) can be used for in vitro manipulations and genetic improvement in cultivars with economic value. During the last decade, protoplast research in economic brown algae has been scarce, and it is usually hampered by the use of non-commercial enzymes or crude extracts for isolating protoplasts. Dictyopteris pacifica is part of a brown algal genus well known by its wide chemical diversity and biological properties. Scytosiphon lomentaria is an edible brown seaweed with antioxidant, antitumor, and antiviral properties. So far, there are no protoplast isolation protocols using commercial enzymes for these two economic brown algae. In this study, we obtained protoplasts from cultured samples of D. pacifica and S. Iomentaria using commercially available enzymes. Additionally, we investigated the effects of Driselase inclusion and Ca-chelation pre-treatment on protoplast yields in order to optimize the conditions for protoplast preparations.

Results: Protoplasts were isolated from Dictyopteris pacifica and Scytosiphon lomentaria using the commercially available Cellulase Onozuka RS (1\%) and Alginate lyase $\left(4 \mathrm{U} \mathrm{mL}^{-1}\right)$, and short incubation time (4 h). Driselase did not show significant effects on protoplast production in both species. Ca-chelation pre-treatment only increased the number of protoplasts in D. pacifica. Under optimal conditions, the protoplast yields from D. pacifica and S. lomentaria were $4.83 \pm 2.08$ and $74.64 \pm 32.49 \times 10^{6}$ protoplasts $\mathrm{g}^{-1}$ fresh weight, respectively. The values obtained for $\mathrm{S}$. lomentaria were $2-3$ orders of magnitude higher than previously reported.

Conclusions: Our results show that high protoplast yields can be obtained from D. pacifica and S. lomentaria using a simple mixture of commercial enzymes (Cellulase RS and Alginate lyase) and short incubation time $(4 \mathrm{~h}$ ). This work also represents the first report of protoplast isolation in D. pacifica. The method proposed here can help to expand protoplast technology in more brown algal species.
\end{abstract}

Keywords: Brown algae, Commercial enzymes, Dictyopteris pacifica, Scytosiphon lomentaria, Protoplast isolation, Cultured samples

\section{Background}

Protoplasts are cells whose cell walls have been removed mostly by enzymatic methods. Although they are usually produced from plant cells, protoplasts can also be obtained from bacteria [1] and fungi [2]. Protoplasts

\footnotetext{
*Correspondence: tocho@chosun.ac.kr

'Department of Life Science, Chosun University, Gwangju 61452, Korea ${ }^{2}$ Department of Integrative Biological Sciences \& BK21 FOUR Educational Research Group for Age-associated Disorder Control Technology, Chosun University, Gwangju 61452, Korea
}

\section{Springer Open}

represent a powerful experimental material for in vivo manipulations, offering a wide range of applications for basic and applied research, including genome-editing and gene silencing techniques, and crop improvement bypassing sexual reproduction from species of economic importance [3-5]. The success of this technology relies on reproducible protocols for protoplast isolation, which are mainly achieved by using commercial enzymes [6, 7].

Brown algae are a diverse group of photosynthetic organisms. They are mainly distributed in marine 
environments and encompass species that are used in human food, animal feed, and traditional medicine [8, 9]. Protoplast isolation has been reported in 33 species of marine brown algae [4, 10-12], including some commercial species like Undaria pinnatifida (Harvey) Suringar and Saccharina japonica (Areschoug) C.E.Lane, C.Mayes, Druehl \& G.W.Saunders [4]. However, protoplast production in other economic brown algae has remained largely unexplored as works on this topic have become scarce during the last decade. In addition, most protocols rely on non-commercial enzymes or crude extracts for protoplast isolation, which make them expensive, time consuming and low reproducible $[6,7]$.

Dictyopteris pacifica (Yendo) I.K.Hwang, H.-S.Kim \& W.J.Lee is an epilithic brown seaweed with a complanate and subdichotomous thallus with a matted rhizoidal holdfast. It is endemic from the coasts of Korea and Japan [13]. Studies on vitamins and related substances have shown that this species contains nicotinic and folic acid that play a key role in human energy metabolism $[14,15]$ and lipoic acid might serve as ancillary treatment for many diseases, such as diabetes and cancer [14, 16]. Also, D. pacifica is part of a brown algal genus well known by its wide chemical diversity and biological properties [17]. So far, there has not been reports on protoplast isolation in this species.

Scytosiphon lomentaria (Lyngbye) Link is tubularshaped brown algal species distributed in temperate seas worldwide [18]. It is considered a traditional food in China, Taiwan, western coast of Japan and southern coast of Korea. This important economic seaweed has a delicious taste and high nutritional value [19]. This alga is variably consumed as dried food in Japan, boiled soup in China, and mixed food with pork in Taiwan [18, 20, 21]. In addition, S. lomentaria has shown promising biomedical applications [21, 22]. Protoplast isolation in $S$. lomentaria has been accomplished once using a complex mixture of commercial enzymes and a crude extract from the marine herbivore Trochus maculatus Linnaeus [23].

This research aims to develop a protocol for protoplast production from Dictyopteris pacifica and Scytosiphon lomentaria as an effort to expand protoplast technology in commercial brown algae. We isolated the protoplasts from laboratory culture samples using a simple mixture of commercial enzymes. The reason for choosing cultured thalli was that they offer an advantage over field samples in terms of applicability, as the former meets the need for protoplast transformation regarding genetic background [24]. So far, protoplast isolation in S. lomentaria and other Dictyopteris species has been performed on field materials $[23,25,26]$. In addition, we tested the effect of Driselase inclusion and Ca-chelation pretreatment on protoplast production to determine the best conditions for this process.

\section{Methods}

Seaweed collection and culture

Dictyopteris pacifica was collected at Uljin, Gyeongsangbuk-do, Korea. Representative voucher specimen (MBRB0013TC19281C1, =CUK19281) examined in this study was deposited in the herbarium. Monosporangial germlines were easily detached from old sporophytes in the laboratory and cultured in $60 \times 15 \mathrm{~mm}$ Petri dishes containing Provasoli-enriched seawater (PES) medium under $14: 10$-h light/dark photoperiod at $20{ }^{\circ} \mathrm{C}$ with light intensity of $40 \mu \mathrm{mol}$ photons $\mathrm{m}^{-2} \mathrm{~s}^{-1}$ of white LED (DyneBioCo. Korea). To avoid further diatom contamination, $\mathrm{GeO}_{2}$ at a final concentration of $6 \mathrm{mg} \mathrm{L}^{-1}$ was added to the culture media. Monosporangial germlines produced filaments. Filaments were transferred to 1-L flat-bottomed round flasks filled with $1 \mathrm{~L}$ PES medium, under aeration, with a light intensity of 40-72 $\mu \mathrm{mol}$ photons $\mathrm{m}^{-2} \mathrm{~s}^{-1}$ of white fluorescent light. The temperature and photoperiod were the same as indicated above.

Scytosiphon lomentaria was collected at Gijang, Busan, Korea. Representative voucher specimen (MBRB0045TC19303C1, =CUK19303) examined in this study was deposited in the herbarium. For culture, thallus was cleaned with sterile seawater in the laboratory, and it started to release spores after $10 \mathrm{~min}$. These were isolated using the hanging-drop technique and then transferred to a $60 \times 15 \mathrm{~mm}$ Petri dishes containing PES medium under the same conditions for Dictyopteris pacifica.

\section{Identification of the samples}

Taxonomic identification was performed using morphological characters according Boo [18], and Lee and Hwang [13], and confirmed molecularly. Genomic DNA extraction, PCR amplification, DNA purification, and sequencing were performed according to Bustamante et al. [27] using cultured samples. The plastid $r b c \mathrm{~L}$ was amplified using the primer combinations described by Kogame et al. [28]. The amplified gene sequences were compared to the GenBank nucleotide database using the BLAST program [29].

\section{Protoplast isolation}

The commercially available cell wall lytic enzymes used for this study included Cellulase Onozuka RS (Yakult Co. Ltd., Japan), Alginate lyase, and Driselase ${ }^{\mathrm{rm}}$ Basidiomycetes sp. (Sigma-Aldrich, USA). The combinations and conditions for enzymes are shown in Table 1.

Protoplast isolation was carried out as previously described protocol by Coelho et al. [30] with some modifications. Briefly, approximately $100-300 \mathrm{mg}$ of 4-6 $\mathrm{mm}^{2}$ explants from cultured foliose thalli of Dictyopteris pacifica (4-5 cm in length) or macrothalli of Scytosiphon lomentaria (2-3 cm in length) were incubated in a $0.22-\mu \mathrm{m}$ filter-sterilized enzymatic solution at 20 
Table 1 Combinations and concentrations of enzyme mixtures for protoplast isolation from Dictyopteris pacifica and Scytosiphon lomentaria

\begin{tabular}{lllll}
\hline Commercial enzymes & \multicolumn{4}{l}{ Composition of enzyme mixtures } \\
\cline { 2 - 5 } & A & B & C & D \\
\hline Cellulase Onozuka RS (\%) & 1 & 1 & 1 & 1 \\
Alginate lyase $\left(\mathbf{U ~ m L}^{-1}\right)$ & 4 & 4 & 4 & 4 \\
Driselase (\%) & 1 & - & 1 & - \\
Chelation pre-treatment & No & No & Yes & Yes \\
\hline
\end{tabular}

${ }^{\circ} \mathrm{C}$, pH 6 with shaking at $70 \mathrm{rpm}$ in the dark. The solution consisted of $400 \mathrm{mM} \mathrm{NaCl}, 130 \mathrm{mM} \mathrm{MgCl} \cdot 6 \mathrm{H}_{2} \mathrm{O}$, $22 \mathrm{mM} \mathrm{MgSO}_{4}, 160 \mathrm{mM} \mathrm{KCl}, 2 \mathrm{mM} \mathrm{CaCl}_{2}$, and 10 mM MES, containing Cellulase Onozuka RS and Alginate lyase, either with or without Driselase. The osmolarity of the enzymatic solution was $1570 \mathrm{mOsm} \mathrm{L}^{-1}$ $\mathrm{H}_{2} \mathrm{O}$. After preliminary experiments, incubation time was set at $4 \mathrm{~h}$ for both species.

The inclusion of Driselase was assessed together with Ca-chelation pre-treatment, which was conducted with a calcium-chelating solution $[665 \mathrm{mM} \mathrm{NaCl}, 30 \mathrm{mM}$ $\mathrm{MgCl}_{2} \cdot 6 \mathrm{H}_{2} \mathrm{O}, 30 \mathrm{mM} \mathrm{MgSO}{ }_{4}, 20 \mathrm{mM} \mathrm{KCl}$, and $20 \mathrm{mM}$ ethylene glycol-bis( $\beta$-amino-ethyl ether)- $N, N, N^{\prime}, N^{\prime}$ ethylene glycol-bis( $\beta$-amino-salt $\left(E G T A-\mathrm{Na}_{4}\right)$ as the calcium chelator; pH5.5] for 20 min prior to enzymatic digestion [30]. Protoplast isolation was repeated four times in each treatment.

Protoplast purification was performed according to Avila-Peltroche and Won [12]. Protoplast yield was estimated by using a hemocytometer (Marienfeld, Germany) and expressed as protoplasts $\mathrm{g}^{-1}$ fresh weight (FW). Protoplast size was calculated by using Image $1.46 \mathrm{r}$ software (NIH, Bethesda, MD, USA) based on 100 cell measurements for each repetition.

\section{Viability and cell wall removal}

The viability of protoplasts and cell wall removal were assessed by the red chlorophyll autofluorescence and staining with calcofluor white M2R (Sigma-Aldrich, USA), respectively, as previously described [11]. Protoplast viability was further confirmed by using $2.4 \mu \mathrm{M}$ fluorescein diacetate (FDA; Sigma, USA) and observed under a Leica DMi8 inverted microscope equipped with a $540 / 46 \mathrm{~nm}$ emission filter and a $590 \mathrm{~nm}$ suppression filter.

\section{Statistical analysis}

Normality and homoscedasticity were examined by using the Shapiro-Wilk and Levene tests, respectively, prior to conducting parametric tests. Two-way analysis of variance (ANOVA) was used for the comparison of protoplast yield under Driselase inclusion and Ca-chelation pre-treatment. Effect sizes were presented as $\omega^{2}$ [31] in case of significant results. All these analyses were performed using "car" [32] and "userfriendlyscience" [33] packages in $\mathrm{R}$ [34].

Tukey's post hoc test was used when the results were significant. Post-hoc comparisons were conducted using "multcomp" [35] or "userfriendlyscience" [33] packages in R. For statistical analyses, the significance threshold was set at $p=0.01$ in order to reduce the true type I error rate (at least 7\%, but typically close to $15 \%$ ) [36]. All graphs were created in Graphpad Prism 6.0 (GraphPad Software, USA).

\section{Results}

\section{Identification}

In our cultures, monosporangial germlines from Dictyopteris pacifica produced filaments in petri dishes after 2-3 weeks (Fig. 1a). Filaments developed foliose thalli with subdichotomous blades of $4-5 \mathrm{~cm}$ in length in $1 \mathrm{~L}$ flask after 1 month and 1 week (Fig. 1b). The blades had the weak midrib, a key character for this species [13]. Our morphological identification of $D$. pacifica was confirmed by molecular analysis. The $r b c \mathrm{~L}$ region (1300-bp) (MW715817) of our strain was $100 \%$ identical to field samples of D. pacifica from Korea and Japan [37].

Spores of Scytosiphon lomentaria produced prostrate filamentous thalli. Tubular macrothalli of about $2-3 \mathrm{~cm}$ in length were formed in $1 \mathrm{~L}$ flask after 2 months in culture (Fig. 2a, b). They were matched with the description provided by Womersley [38]. Although the thalli did not show marked constrictions as reported by Boo [18], molecular analysis using a $r b c \mathrm{~L}$ region (1342-bp) (MW715818) of our strain was matched with $99.85 \%$ to field samples of $S$. lomentaria from Korea and Japan [39].

\section{Protoplast isolation}

Protoplast yields from Dictyopteris pacifica ranged from 1 to $5 \times 10^{6}$ protoplasts $\mathrm{g}^{-1} \mathrm{FW}$ (Table 2). Mixture C (Cellulase RS, Alginate lyase, and Driselase with Cachelation pre-treatment) and D (Cellulase RS and Alginate lyase with $\mathrm{Ca}$-chelation pre-treatment) produced the large number of protoplasts (Table 2). Two-way ANOVA revealed that pre-treatment had a significant effect on protoplast production $\left(p<0.001 ; \omega^{2}=0.63\right)$. Explants pre-treated with $\mathrm{Ca}$-chelation solution reported about 3 times more protoplasts than those ones without pre-treatment. The inclusion of Driselase did not improve protoplast yields $(p=0.573)$. The interaction between both factors did not have a significant effect ( $p=$ 0.587). Numerous protoplasts were isolated from the cortex and medulla of the blades. Protoplasts were pale yellow-brown to dark brown, spherical shape with several discoid chloroplast (Fig. 1c, d). They were $26.59 \pm$ 

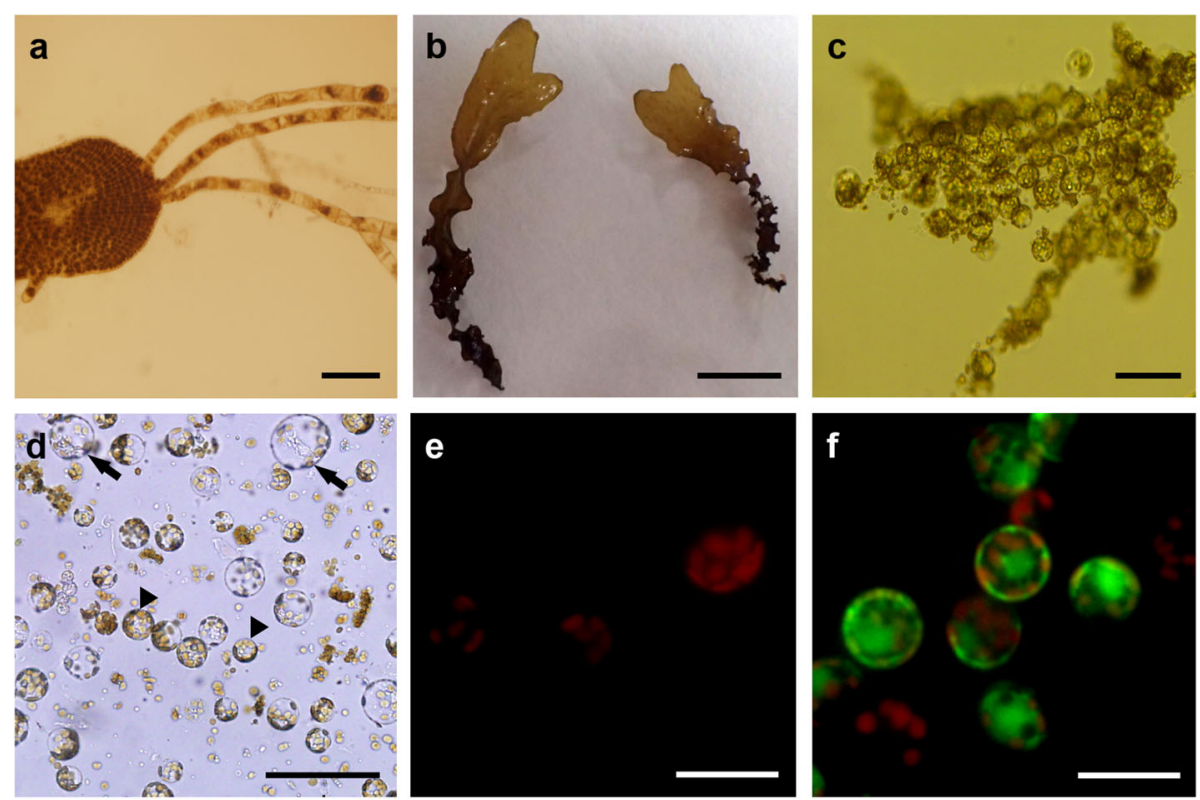

Fig. 1 Protoplast isolation from Dictyopteris pacifica. a A germline blade producing filaments in cultures without aeration (bar $=200 \mu \mathrm{m})$. b Foliose thalli after 1 month in suspension culture $(\mathrm{bar}=1 \mathrm{~cm}$ ). $\mathbf{c}$ Spherical protoplasts from blade after $2 \mathrm{~h}$ of enzymatic digestion (bar $=100$ $\mu \mathrm{m})$. d Freshly isolated protoplasts produced from the cortex (arrowheads) and medulla (arrows) (bar $=100 \mu \mathrm{m})$. e True protoplasts with red chlorophyll autofluorescence under inverted fluorescence microscope showing no cell walls (bar $=10 \mu \mathrm{m})$. f Protoplasts with green fluorescence stained with FDA showing their viability (bar $=10 \mu \mathrm{m})$
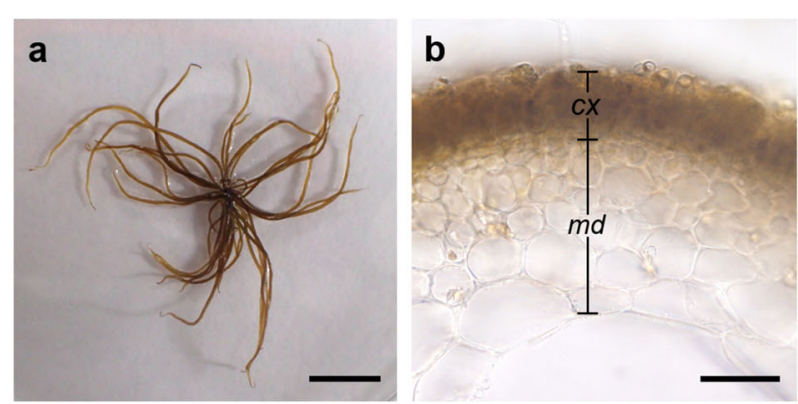

C
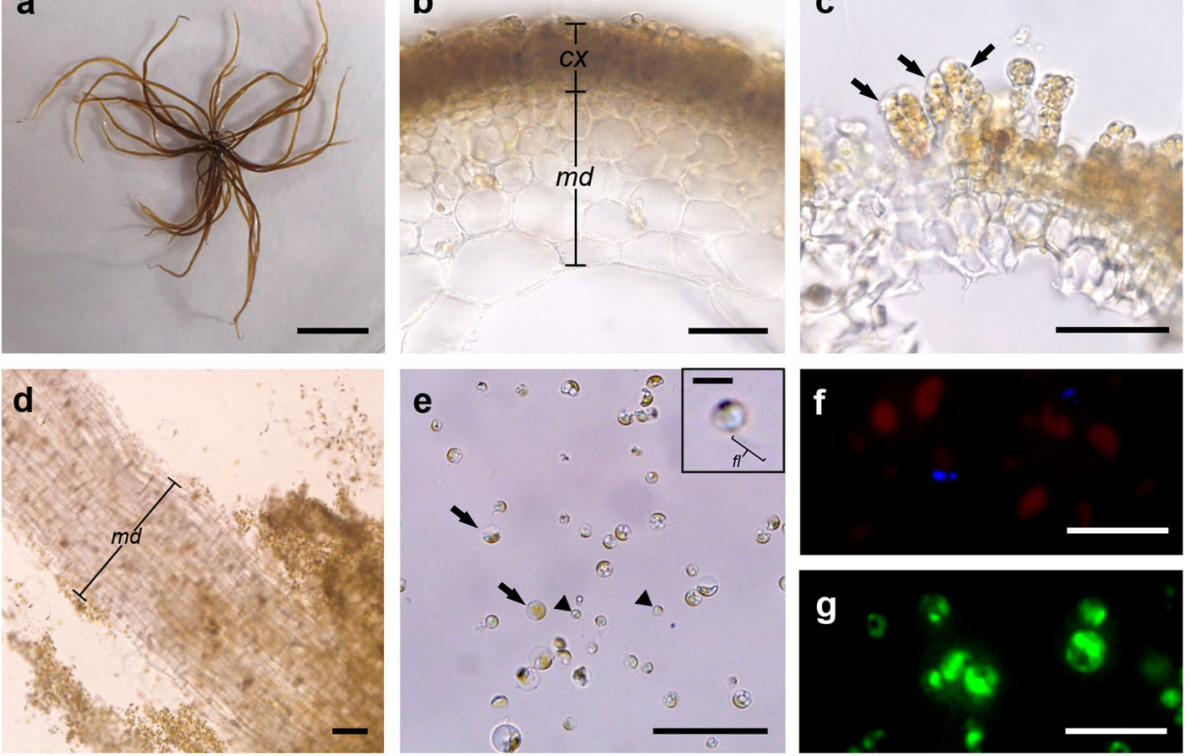

Fig. 2 Protoplast isolation from Scytosiphon lomentaria. a Mature macrothalli after 2 months in suspension culture (bar $=1 \mathrm{~cm}$ ). $\mathbf{b} \mathrm{Cross}$ section view of macrothallus showing cortex $(c x)$ and medulla $(m d)(b a r=50 \mu m)$. c Plurilocular sporangia (arrows) from a mature macrothallus (bar $=50$ $\mu \mathrm{m})$. d Thallus under enzymatic process showing undigested medulla ( $\mathrm{md}$ ) (bar $=100 \mu \mathrm{m})$. e Freshly isolated protoplasts (arrows) from somatic cells and zooids (arrowheads) with flagellum ( $f$ ) from digested plurilocular sporangia (bar $=50 \mu \mathrm{m}$; bar in inset $=5 \mu \mathrm{m}$ ). f True protoplasts with red chlorophyll autofluorescence under inverted fluorescence microscope showing no cell walls $(b a r=10 \mu m)$. g Protoplasts with green fluorescence stained with FDA showing their viability $($ bar $=10 \mu \mathrm{m})$ 
Table 2 Protoplast yield of Dictyopteris pacifica and Scytosiphon lomentaria obtained from different enzyme combinations

\begin{tabular}{|c|c|c|}
\hline \multirow{2}{*}{$\begin{array}{l}\text { Enzyme } \\
\text { mixtures }\end{array}$} & \multicolumn{2}{|c|}{ Protoplast yield $\left(\times 10^{6}\right.$ protoplasts $\mathrm{g}^{-1}$ fresh weight } \\
\hline & Dictyopteris pacifica & Scytosiphon lomentaria \\
\hline A & $1.98 \pm 0.53^{\mathrm{a}}$ & $65.54 \pm 18.69^{a}$ \\
\hline B & $1.25 \pm 0.67^{\mathrm{a}}$ & $74.64 \pm 32.49 a$ \\
\hline C & $4.85 \pm 1.21^{\mathrm{b}}$ & $76.54 \pm 20.27^{\mathrm{a}}$ \\
\hline D & $4.83 \pm 2.08^{b}$ & $57.82 \pm 11.39^{\mathrm{a}}$ \\
\hline
\end{tabular}

Superscript letters indicate significant differences among enzyme mixtures for each species $(p<0.01)$. Values are presented as mean \pm SD $(n=4)$

$5.90 \mu \mathrm{m}$ (range, $13-52 \mu \mathrm{m}$ ) in diameter. Percentages of true protoplast were $99-100 \%$ with calcofluor white staining. The viability of freshly isolated protoplasts was 98-100\% with red chlorophyll autofluorescence, and 70\% with FDA staining (Fig. 1e, f).

Protoplast yields from Scytosiphon lomentaria ranged from 58 to $77 \times 10^{6}$ protoplasts $\mathrm{g}^{-1} \mathrm{FW}$ (Table 2). Mixture C (Cellulase RS, Alginate lyase, and Driselase with Ca-chelation pre-treatment) and B (Cellulase RS and Alginate lyase without $\mathrm{Ca}$-chelation pre-treatment) produced the large number of protoplasts (Table 2). Twoway ANOVA revealed that pre-treatment did not improve protoplast production $(p=0.664)$, while the inclusion of Driselase was not critical for enhancing protoplast yields $(p=0.548)$. After enzymatic digestion, two distinct populations were found with different sizes: protoplasts originating from vegetative cells of the cortex, and more or less mature zooids from digested plurilocular sporangia (Fig. 2c, e; Fig. 3). Medulla were mostly undigested (Fig. 2d). Protoplasts were pale yellow-brown, spherical shape with a single discoid chloroplast. Percentages of true protoplast were 99$100 \%$ with calcofluor white staining. The viability of freshly isolated protoplasts was $98-100 \%$ with red

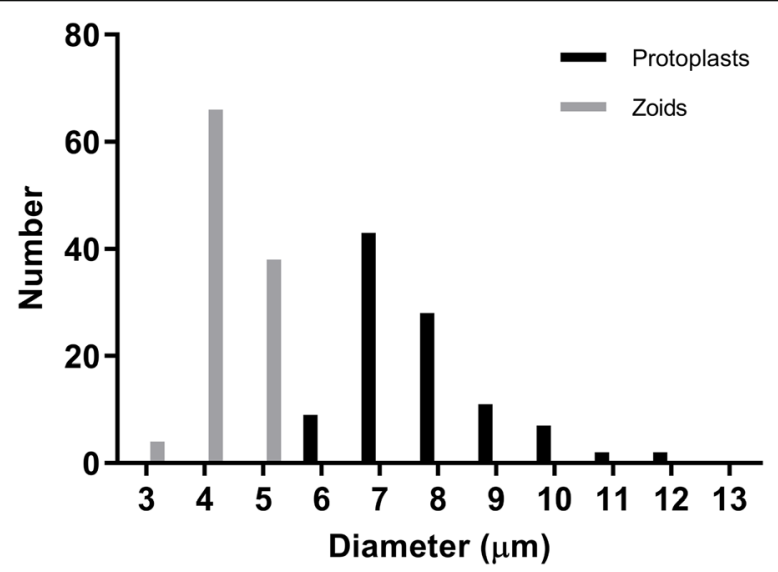

Fig. 3 Distribution of the size of somatic cell protoplasts and zooids from Scytosiphon lomentaria chlorophyll autofluorescence and 83\% with FDA staining (Fig. 2f, g).

\section{Discussion}

In this study, we report the production of high yields of viable and true protoplasts from two economic brown algal species, Dictyopteris pacifica and Scytosiphon lomentaria, using a simple mixture of commercial enzymes.

For first time, we obtained protoplasts from Dictyopteris pacifica in large numbers $\left(1-5 \times 10^{6}\right.$ protoplasts $\mathrm{g}^{-1} \mathrm{FW}$ ) using commercial Cellulase RS and Alginate lyase. Our values were inferior to protoplast yields from D. prolifera (Okamura) Okamura $\left(3.3 \times 10^{7}\right.$ protoplasts $\left.\mathrm{g}^{-1} \mathrm{FW}\right)[26]$ and D. undulata Holmes $\left(8.2 \times 10^{6}\right.$ protoplasts $\left.g^{-1} \mathrm{FW}\right)$ [25]. However, in these species, protoplasts were produced using a mixture of commercial enzymes and crude extracts from marine herbivores. Cachelation pre-treatment was necessary for improving protoplasts yields in $D$. pacifica. This positive effect has been also reported in Ectocarpales [30, 40] and Laminariales [41].

Protoplasts from Scytosiphon lomentaria were produced in high numbers $\left(5.8-7.7 \times 10^{7}\right.$ protoplasts $\mathrm{g}^{-1}$ FW) using a simple enzyme combination of Cellulase RS and Alginate lyase in a single-step method (without pretreatment). Yamaguchi et al. [23] isolated $10^{4}-10^{5}$ protoplasts $\mathrm{g}^{-1} \mathrm{FW}$ from $S$. lomentaria using a complex mixture of commercial enzymes and hepatopancreas extract from the marine herbivore Trochus maculatus. Our protocol produced 2-3 orders of magnitude more protoplasts than this previous report. The medullary layer of S. lomentaria remained largely undigested, suggesting a different composition of cell wall among cell types. For instance, in brown seaweed Saccharina japonica, epidermal cell wall differs from cortical cell wall in crystallinity of cellulose and its content [7]. Another reason behind the medullary layer resistance to wall breakdown might be the size $\left(4-6 \mathrm{~mm}^{2}\right)$ of explants used in this study. Salvador and Serrano [42] obtained medullary and axial cell protoplasts from the red seaweed Kappaphycus alvarezii (Doty) L.M. Liao by using explants less than $1 \mathrm{~mm}^{2}$. According to these authors, the small size of the fragments increased the surface area in contact with the enzyme mixture and exposed the medullary and axial zones.

As we used mature thalli, zooids were also isolated from plurilocular sporangia. However, they were easily distinguished based on its size, as they were smaller than protoplasts. This difference was also pointed out by Mejjad et al. [40] when isolating protoplasts and zooids from the filamentous brown alga Pylaiella littoralis (Linnaeus) Kjellman.

Despite the presence of mixed-linked glucan (MLG) in brown algal cell walls [43], the use of Driselase, a natural 
enzyme mixture that degrades MLG [44], did not improve protoplast yields in our experiments. Inoue et al. [7] suggested that at least three components were essential for protoplast isolation from Saccharina japonica: cellulase, alginate lyase, and protease. Our results in $S c y$ tosiphon lomentaria and Dictyopteris pacifica suggest that only two components, cellulase and alginate lyase, are sufficient for protoplast production in brown algae. This is consistent with the findings of previous works on filamentous brown algae [11, 12, 45].

In this study, a simple combination of commercial enzymes is essential for establishing reproducible protocols for protoplast isolation. For example, in green marine macroalgae, a simple protocol using only Cellulase Onozuka R-10 has been recently established for consistent production of large amounts of protoplasts [46]. Similarly, commercially available cellulase, macerozyme, and/ or pectinase are routinely used for protoplast isolation in higher plants [47]. The effects of protease inhibitors or protein substrates for inactivating toxic components in the enzyme mixtures were not tested in this work. However, these were not an impediment for obtaining large number of protoplasts. Chen and Shyu [48] suggested that these chemicals might not be necessary when incubation time is short, such as the case in this study. They also pointed out that short digestion times allowed protoplast harvesting before being adversely affected by proteases in the enzyme mixture.

\section{Conclusions}

Our work proposes a simple method for isolating protoplasts from $S$. lomentaria and it represents the first report of protoplast production from $D$. pacifica. In both species, a simple mixture of commercial enzymes (Cellulase RS and Alginate lyase) and short incubation time (4 h) produced high amount of true and viable protoplasts. In D. pacifica, Ca-chelation pre-treatment was critical for improving protoplast production. These findings can help to develop standard protocols for protoplast technology in brown algae.

\section{Abbreviations}

FDA: Fluorescein diacetate; FW: Fresh weight; PES: Provasoli Enriched Seawater

\section{Acknowledgments}

Not applicable.

\section{Authors' contributions}

All authors contributed to the study conception and design. Material preparation, data collection, and analysis were performed by JAP. The first draft of the manuscript was written by JAP and all authors commented on previous versions of the manuscript. All authors read and approved the final manuscript.

\section{Funding}

This research was supported by a 2020 research fund from Chosun University to TOC.

\section{Availability of data and materials}

The data that support the findings of this study are available from the corresponding author, Tae Oh Cho, upon reasonable request.

\section{Declarations}

Ethics approval and consent to participate

Not applicable.

\section{Consent for publication}

Not applicable.

\section{Competing interests}

The authors declare that they have no competing interests.

Received: 21 May 2021 Accepted: 9 August 2021

Published online: 03 September 2021

\section{References}

1. Kami S, Tsuchikado R, Nishida H (2019) DNA replication and cell enlargement of Enterococcus faecalis protoplasts. AIMS Microbiol 5(4):347357. https://doi.org/10.3934/microbiol.2019.4.347

2. Turgeon BG, Condon B, Liu J, Zhang N (2010) Protoplast transformation of filamentous fungi. In: Sharon A (ed) Molecular and cell biology methods for fungi. Methods in Molecular Biology (Methods and Protocols), volume 638. Humana Press, Totowa

3. Davey MR, Anthony P, Power JB, Lowe KC (2005) Plant protoplasts: status and biotechnological perspectives. Biotechnol Adv 23(2):131-171. https:// doi.org/10.1016/j.biotechadv.2004.09.008

4. Reddy CRK, Gupta MK, Mantri VA, Bhavanath J (2008) Seaweed protoplast: status, biotechnological perspectives and needs. J Appl Phycol 20(5):619632. https://doi.org/10.1007/s10811-007-9237-9

5. Burris KP, Dlugosz EM, Collins AG, Stewart CN, Lenaghan SC (2016) Development of a rapid, low-cost protoplast transfection system for switchgrass (Panicum virgatum L.). Plant Cell Rep 35(3):693-704. https://doi. org/10.1007/s00299-015-1913-7

6. Gupta V, Kumar M, Kumari P, Reddy CRK, Jha B (2011) Optimization of protoplast yields from the red algae Gracilaria dura (C. Agardh) J. Agardh and G. verrucosa (Huds.) Papenfuss. J Appl Phycol 23(2):209-218. https://doi. org/10.1007/s10811-010-9579-6

7. Inoue A, Mashino C, Kodama T, Ojima T (2011) Protoplast preparation from Laminaria japonica with recombinant alginate lyase and cellulase. Mar Biotechnol 13(2):256-263. https://doi.org/10.1007/s10126-010-9290-2

8. Liu L, Heinrich M, Myers S, Dworjanyn S (2012) Towards a better understanding of medicinal uses of the brown seaweed Sargassum in Traditional Chinese Medicine: a phytochemical and pharmacological review. J Ethnopharmacol 142(3):591-619. https://doi.org/10.1016/j.jep.2012.05.046

9. Sanjeewa KKA, Jeon Y-J (2018) Edible brown seaweeds: a review. J Food Bioact 2:37-50

10. Fisher DD, Gibor A (1987) Production of protoplasts from the brown alga, Sargassum muticum (Yendo) Fensholt (Phaeophyta). Phycologia 26(4):488495. https://doi.org/10.2216/i0031-8884-26-4-488.1

11. Avila-Peltroche J, Won BY, Cho TO (2019) Protoplast isolation and regeneration from Hecatonema terminale (Ectocarpales, Phaeophyceae) using a simple mixture of commercial enzymes. J Appl Phycol 31(3):18731881. https://doi.org/10.1007/s10811-018-1660-6

12. Avila-Peltroche J, Won BY (2020) Protoplast production from Sphacelaria fusca (Sphacelariales, Phaeophyceae) using commercial enzymes. J Mar Biosci Biotechnol 12:50-58 https://doi.org/10.15433/ksmb.2020.12.1.050

13. Lee JW, Hwang IK (2010) Dictyotales, Desmarestiales. In Shin S (ed) Algal flora of Korea, volume 2, number 2. Heterokontophyta: Phaeophyceae: Ishigeales, Dictyotales, Desmarestiales, Sphacelariales, Cutleriales, Ralfisales, Laminariales. Marine Brown Algae II. National Institute of Biological Resources, Incheon

14. Nisizawa K (1979) Pharmaceutical studies on Marine Algae of Japan. In: Hoppe HA, Levring T, Tanaka Y (eds) Marine Algae in Pharmaceutical Science, volume 1. De Gruyter, Berlin

15. Huskisson E, Maggini S, Ruf M (2007) The role of vitamins and minerals in energy metabolism and well-being. J Int Med Res 35(3):277-289. https://doi. org/10.1177/147323000703500301 
16. Gorąca A, Huk-Kolega H, Piechota A, Kleniewska P, Ciejka E, Skibska B (2011) Lipoic acid-biological activity and therapeutic potential. Pharmacol Rep 63 849-858 https://doi.org/10.1016/S1734-1140(11)70600-4

17. Zatelli GA, Philippus AC, Falkenberg M (2018) An overview of odoriferous marine seaweeds of the Dictyopteris genus: insights into their chemical diversity, biological potential and ecological roles. Rev Bras 28(2):243-260. https://doi.org/10.1016/j.bjp.2018.01.005

18. Boo SM (2010) Scytosiphonaceae, Petrospongiaceae. In: Kim HS, Boo SM (eds) Algal flora of Korea, volume 2, number 1. Heterokontophyta: Phaeophyceae: Ectocarpales. Marine brown algae I. National Institute of Biological Resources, Incheon

19. Zhang Y, Fu XT, Lin H, Xu JC, Gao X (2011) Analysis and evaluation of nutritional quality of Scytosiphon lomentsrius. Acta Nutrimenta Sin 33:619623 (in Chinese with English abstract)

20. Bangmei X, Abbott IA (1987) Edible seaweeds of China and their place in the Chinese diet. Econ Bot 41(3):341-353. https://doi.org/10.1007/BF0285904 9

21. Kuda T, Tsunekawa M, Hishi T, Araki Y (2005) Antioxidant properties of dried 'kayamo-nori', a brown alga Scytosiphon lomentaria (Scytosiphonales, Phaeophyceae). Food Chem 89(4):617-622. https://doi.org/10.1016/j. foodchem.2004.03.020

22. Ponce NM, Flores ML, Pujol CA, Becerra MB, Navarro DA, Córdoba O, Damonte EB, Stortz CA (2019) Fucoidans from the phaeophyta Scytosiphon Iomentaria: Chemical analysis and antiviral activity of the galactofucan component. Carbohydr Res 478:18-24. https://doi.org/10.1016/j.carres.2019. 04.004

23. Yamaguchi K, Araki T, Aoki T, Tseng C, Kitamikado M (1989) Algal cell wall degrading enzymes from viscera of marine animals. Nippon Suisan Gakkai Shi 55(1):105-110. https://doi.org/10.2331/suisan.55.105

24. Wu C, Jiang P, Zhao J, Fu H (2018) High efficiency of protoplast preparation for artificially cultured Ulva prolifera (Ulvophyceae, Chlorophyta). J Ocean Limnol 36(5):1806-1811. https://doi.org/10.1007/s00343-018-7058-0

25. Kajiwara T, Hatanaka A, Fujimura T, Kawai T, Irie M (1988) Isolation of protoplasts from marine brown algae Dictyotaceae plants. Nippon Suisan Gakkai Shi 54(7):1255. https://doi.org/10.2331/suisan.54.1255

26. Fujimura T, Kawai T, Kajiwara T, Ishida Y (1995) Protoplast isolation in the marine brown alga Dictyopteris prolifera (Dictyotales). Plant Cell Rep 14(9): 571-574. https://doi.org/10.1007/BF00231940

27. Bustamante DE, Won BY, Cho TO (2016) The conspecificity of Pterosiphonia spinifera and $P$. arenosa (Rhodomelaceae, Ceramiales) inferred from morphological and molecular analyses. Algae 31(2):105-115. https://doi. org/10.4490/algae.2016.31.5.13

28. Kogame K, Horiguchi T, Masuda M (1999) Phylogeny of the order Scytosiphonales (Phaeophyceae) based on DNA sequences of $r b c \mathrm{~L}$, partial rbcS, and partial LSU nrDNA. Phycologia 38(6):496-502. https://doi.org/1 0.2216/i0031-8884-38-6-496.1

29. Altschul SF, Madden TL, Schäffer AA, Zhang J, Zhang Z, Miller W, Lipman D (1997) Gapped BLAST and PSI-BLAST: a new generation of protein database search programs. Nucleic Acids Res 25(17):3389-3402. https://doi.org/10.1 093/nar/25.17.3389

30. Coelho SM, Scornet D, Rousvoal S, Peters N, Dartevelle L, Peters AF, Cock JM (2012) Isolation and regeneration of protoplast from Ectocarpus. Cold Spring Harb Protoc 2012(3):361-364. https://doi.org/10.1101/pdb.prot067959

31. Lakens D (2013) Calculating and reporting effect sizes to facilitate cumulative science: a practical primer for t-tests and ANOVA. Front Psychol 4:863

32. Fox J, Weisberg S (2019) An R Companion to Applied Regression, 3rd edn Sage, Los Angeles https://socialsciences.mcmaster.ca/jfox/Books/Compa nion/

33. Peters G (2018) userfriendlyscience: Quantitative analysis made accessible. https://doi.org/10.17605/osf.io/txequ. R package version 0.7.2: https:// userfriendlyscience.com

34. R Core Team (2016) R: A language and environment for statistical computing. R Foundation for Statistical Computing, Vienna, Austria. https:// www.R-project.org/. Accessed 3 Mar 2021

35. Hothorn T, Bretz F, Westfall P (2008) Simultaneous inference in genera parametric models. Biom J 50(3):346-363. https://doi.org/10.1002/bimj.20081 0425

36. Sellke T, Bayarri MJ, Berger JO (2001) Calibration of $p$ values for testing precise null hypotheses. Am Stat 55(1):62-71. https://doi.org/10.1198/000313 001300339950
37. Hwang I-K, Kim H-S, Lee WJ (2004) Confirmation on taxonomic status of Spatoglossum pacificum Yendo (Dictyotaceae, Phaeophyceae) based on morphology and plastid protein coding $r b c \mathrm{~L}, r b c \mathrm{~S}, p s a \mathrm{~A}$, and psbA Gene Sequences. Algae 19(3):161-174. https://doi.org/10.4490/ALGAE.2004.19.3.1 61

38. Womersley HBS (1987) The marine benthic flora of southern Australia, part II. South Australian Government Printing Division, Adelaide

39. Cho GY, Kogame K, Kawai H, Boo SM (2007) Genetic diversity of Scytosiphon lomentaria (Scytosiphonaceae, Phaeophyceae) from the Pacific and Europe based on RuBisCO large subunit and spacer, and ITS nrDNA sequences. Phycologia 46:657-665

40. Mejjad M, Loiseaux-de-Goër S, Ducreux G (1992) Protoplast isolation, development, and regeneration in different strains of Pilayella littoralis (L.) Kjellm. (Phaeophyceae). Protoplasma 169(1-2):42-48. https://doi.org/10.1007/ BF01343368

41. Butler DM, Ostgaard K, Boyen C, Evans LV, Jensen A, Kloareg B (1989) Isolation conditions for high yields of protoptasts from Laminaria saccharina and L. digitata (Phaeophyceae). J Exp Bot 40(11):1237-1246. https://doi. org/10.1093/jxb/40.11.1237

42. Salvador RC, Serrano AE (2005) Isolation of protoplasts from tissue fragments of Philippine cultivars of Kappaphycus alvarezii (Solieriaceae, Rhodophyta). J Appl Phycol 17(1):15-22. https://doi.org/10.1007/s10811-0055516-5

43. Salmeán AA, Duffieux D, Harholt J, Qin F, Michel G, Czjzek M, Willats WGT, Hervé C (2017) Insoluble ( $1 \rightarrow 3$ ), ( $1 \rightarrow 4)-\beta-D$-glucan is a component of cell walls in brown algae (Phaeophyceae) and is masked by alginates in tissues. Sci Rep 7(1):2880. https://doi.org/10.1038/s41598-017-03081-5

44. Thibault J-F, Rouau X (1990) Studies on enzymic hydrolysis of polysaccharides in Sugar beet pulp. Carbohydr Polym 13(1):1-16. https://doi. org/10.1016/0144-8617(90)90047-V

45. Avila-Peltroche J, Won BY, Cho TO (2020) Optimization of protoplast isolation from the gametophytes of brown alga Undaria pinnatifida using response surface methodology. J Appl Phycol 32(4):2233-2244. https://doi. org/10.1007/s10811-020-02095-3

46. Gupta V, Reddy CRK (2018) A simple protocol for a rapid and consistent production of a large number of viable protoplasts from the Ulvophycean species. In: Charrier B, Wichard T, Reddy CRK (eds) Protocols for macroalgae research. CRC Press, Boca Raton. https://doi.org/10.1201/b21460-7

47. Neumann KH, Imani J, Kumar A (2009) Plant cell and tissue culture-a tool in biotechnology. Principles and Practice. Springer, Berlin

48. Chen C-S, Shyu J-F (1994) Isolation of protoplasts from four species of brown algae. Bot Bull Acad Sin 35:95-104

\section{Publisher's Note}

Springer Nature remains neutral with regard to jurisdictional claims in published maps and institutional affiliations.

\section{Submit your manuscript to a SpringerOpen ${ }^{\circ}$ journal and benefit from:}

- Convenient online submission

- Rigorous peer review

- Open access: articles freely available online

High visibility within the field

- Retaining the copyright to your article

Submit your next manuscript at $>$ springeropen.com 